\title{
Microbial ecology of biological invasions
}

\author{
Wim H van der Putten ${ }^{1,2}$, John N Klironomos ${ }^{3}$ and David A Wardle ${ }^{4,5}$ \\ ${ }^{1}$ Department of Multitrophic Interactions, Netherlands Institute of Ecology, Heteren, The Netherlands; \\ ${ }^{2}$ Laboratory of Nematology, Wageningen University, Wageningen, The Netherlands; ${ }^{3}$ Department of \\ Integrative Biology, University of Guelph, Guelph, Ontario, Canada; ${ }^{4}$ Department of Forest Vegetation \\ Ecology, Swedish University of Agricultural Sciences, Umea, Sweden and ${ }^{5}$ Landcare Research, Lincoln, \\ New Zealand
}

\begin{abstract}
Invasive microbes, plants and animals are a major threat to the composition and functioning of ecosystems; however, the mechanistic basis of why exotic species can be so abundant and disruptive is not well understood. Most studies have focused on invasive plants and animals, although few have considered the effects of invasive microbes, or interactions of invasive plant and animal species with microbial communities. Here, we review effects of invasive plants on soil microbial communities and discuss consequences for plant performance, plant community structure and ecosystem processes. In addition, we briefly discuss effects of invasive soil microbes on plant communities, which has been less well studied, and effects of invasive animals on soil decomposers and ecosystem functioning. We do this by considering each of three important functional groups of microbes, namely soil microbial parasites and pathogens, mutualistic symbionts and decomposers. We conclude that invasive plants, pathogenic and symbiotic soil microbes will have strongest effects on the abundance of individual species, community diversity and ecosystem functioning. Invasive decomposer microbes probably have little impact, because of limited specificity and great functional redundancy. However, invasive plants and animals can have major effects on microbial decomposition in soil. We propose that understanding, predicting and counteracting consequences of enhanced global homogenization of natural communities through introducing exotic plants, animals and microbes will require future studies on how pathogenic, symbiotic and decomposer soil microbes interact, how they are influenced by higher trophic level organisms and how their combined effects are influencing the composition and functioning of ecosystems.
\end{abstract}

The ISME Journal (2007) 1, 28-37; doi:10.1038/ismej.2007.9

Keywords: plant invasion; invasive soil microbes; invasive animals; natural enemies; ecosystem processes; climate warming

\section{Introduction}

One of the major challenges of ecology is to understand what controls the abundance and diversity of species, how these are influenced by natural or human-induced changes, and what are the consequences for ecosystem processes and properties. The difficulties that we have in understanding and forecasting biological invasions show that there are major questions to be solved, especially because globalization and climate warming enhance the movement of species and, therefore, the incidence of invasive species. Biological invasions of exotic species are considered to be among the most serious threats to local biodiversity and ecosystem functioning in terrestrial ecosystems (Mooney and Hobbs,

Correspondence: Professor WH van der Putten, Department of Multitrophic Interactions, Netherlands Institute of Ecology, PO Box 40, Boterhoeksestraat 48, 6666 ZG Heteren, The Netherlands. E-mail: w.vanderputten@nioo.knaw.nl

Received 5 February 2007; revised and accepted 21 February 2007
2000). Traditionally, there has been much interest in the visible components of ecosystems, such as invasive plants and aboveground animals (Elton, 1958; Williamson, 1996). However, these visible biota can have major impacts on the more invisible, microbial components of ecosystems and on the processes that microbes drive. Moreover, there is increasing awareness of invasive microbes, including human, animal or plant diseases, which can in some cases change the appearance and functioning of entire ecosystems (Liebhold et al., 1995; Gerlach, 2001; Jules et al., 2002; Niwa et al., 2004; Waring and O'Hara, 2005).

Here, we will review effects of invasive plants on soil microbial communities and native plant community composition. In addition, we will briefly review effects of invasive soil microbes on plant communities and effects of invasive animals on soil microbial communities and ecosystem processes. Our review is not exhaustive, but it shows the current trends in this field of ecology, and our length of discussion on the several topics is roughly in 
balance with the available information. In doing this, we will also assess the consequences for ecosystem properties. We focus on this belowaboveground interface because, despite being a long history of work in this area, it is only in the last few years that this area has begun to attract substantial interest from ecologists at large (Hooper et al., 2000; Wolters et al., 2000; Scheu, 2001; Van der Putten et al., 2001; Wardle et al., 2004).

Biological invasions involve exotic species that have been introduced, accidentally or incidentally, from one region into another region separated by geographical barriers, such as oceans or mountain ridges and which become non-proportionally abundant in their new range (Williamson, 1996). There are numerous documented examples of biological invasions, but the number of examples involving soil microbes are relatively rare. Thus far, research on biological invasions has been strongly dominated by studies that describe patterns, whereas only some $5 \%$ of the published studies have attempted to experimentally analyse what causes biological invasions (Levine et al., 2003). Of the many hypotheses that have been developed to explain the invasiveness of species and the susceptibility of communities to be invaded, enemy release and biotic resistance (Keane and Crawley, 2002) are prominent hypotheses that have resulted in some promising tests. As a rule of thumb, one out of every thousand introduced species becomes invasive (Williamson, 1996). Invasive organism ecology is, therefore, focused on explaining why a tenth of a percent of cases results in an observed phenomenon.

There is substantial knowledge on how abiotic and biotic soil properties interact with vegetation (Wardle, 2002). These interactions operate at local scales, because at larger spatial scales, soil and plant communities are influenced by soil type and climate (Swift et al., 1979; Lavelle et al., 1993). However, the local feedback interactions between plants and soil microbes have been shown to strongly influence both plant and soil community composition and ecosystem processes (Van Breemen and Finzi, 1998; Bever, 2003). Plants interact most intimately with symbiotic mutualists, pathogens and herbivores in their rhizosphere, whereas interactions with decomposer organisms are more indirect, through root exudates, litter and mineralized nutrients (Figure 1). All these processes can be strongly influenced by invasive species, when they introduce novel properties, such as nitrogen fixation (Vitousek et al., 1979), chemical control of local symbiotic mycorrhizal fungi (Stinson et al., 2006), pathogen resistance (Reinhart et al., 2003) or when they produce organic matter of different quality (Ehrenfeld, 2003). Invasive microbes can change these ecosystem processes when they disturb local patterns of symbiosis, pathogenicity or when they disturb local decomposition processes.

In the next sections, we provide a more detailed review on these issues. As most studies focus on



Figure 1 Interactions between plants, belowground and aboveground ecosystem components. Shaded boxes represent components of which biological invasions have been reported to impact on biodiversity and/or ecosystem processes. Whereas pathogens and symbionts interact directly with living plant roots, decomposers interact more indirectly, through litter decomposition or consumption of root exudates. Interactions $1-5$ have been relatively well studied from the perspective of plant-microbe interactions and aboveground herbivore-plant-decomposer interactions. We propose that interactions between and among pathogens, symbionts and decomposers (6-8) require more attention, as these may influence interactions $1-5$. Higher trophic level interactions, such as outlined for the belowground subsystem by arrows 9-16, are usually ignored when considering biological invasions. We propose that such multitrophic interactions need to be included in future studies in order to enhance our understanding of how invaders disrupt bottom-up and top-down interactions in soil food webs and below-aboveground interaction webs.

either plant-pathogen or plant-symbiont or plantdecomposer interactions, we have structured our review accordingly. In each section, we also review studies that have investigated effects of invasive microbes on plant communities. In the case of soil decomposers, there is no study that has addressed introduced decomposer microbes. Instead, we review some studies on introduced animals, which had major impacts on decomposition and on plant community performance. We will discuss challenges for future studies and propose that besides linking above- and belowground interactions we also need to link direct and indirect belowground interactions, as well as higher trophic levels in the soil food web in order to get a better understanding of how exotic species influence soil subsystems, soil-plant and below-aboveground multitrophic interactions. 


\section{Invasive plants and soil microbial parasites and pathogens}

Traditionally, phytopathologists did not consider that pathogens might play a major role in natural ecosystems, because disease symptoms that appeared in agricultural crops were not commonly observed in nature (Burdon, 1987). More recently, however, ecologists have become aware that microbial pathogens play a major role in the evolution of populations (Clay and Kover, 1996) and in the species composition of natural communities (Burdon, 1993). Effects of pathogens in nature are, however, more incipient because diseased plants are replaced by other genotypes or species. Evidence is accumulating that soil pathogens play a major role in structuring plant community composition (Van der Putten et al., 1993; Bever, 1994; Packer and Clay, 2000; Klironomos, 2002; Kardol et al., 2006). An important prerequisite is that soil pathogens are specific or selective to certain host genotypes or species, and that plants selectively stimulate soil pathogens, as they do with other soil microbes (Bever et al., 1997; Grayston et al., 1998; Marilley et al., 1998; Kowalchuk et al., 2002). Evidence for selective stimulation comes from plant-soil feedback studies (Bever et al., 1997), although these studies provide net effects of the whole soil community, including symbionts and decomposers (Reinhart and Callaway, 2006). However, selective isolation and inoculation of pathogenic soil microbes has provided evidence for a number of case studies that the root zones of wild plant species indeed contain pathogenic soil microbes (De RooijVan der Goes, 1995; Mills and Bever, 1998; Packer and Clay, 2000; Kardol et al., 2007) and that these may be host specific (Van der Putten et al., 2007).

Evidence for the release of invasive plants from soil pathogens would require combined tests in the native and non-native ranges. There are very few such examples where both soil and plants from both native and non-native ranges have been used (Reinhart et al., 2003), whereas most studies did not include both plants and soils from both ranges (Klironomos, 2002; Callaway et al., 2004; Agrawal et al., 2005; Van der Putten et al., 2007). As such, the ultimate test (i.e., the application of Koch's postulates), which also involves collecting and inoculating soil pathogens from both the native and non-native ranges, has not yet been performed. Therefore, the known examples involving release from soil-borne enemies require subsequent evidence in order to more precisely establish the role of release from natural soil microbes in plant invasiveness. Moreover, enemy release studies tend to neglect the possible role of indirect defense against soil-borne pathogens; when plants escape from their natural enemies, they may also lack those microbes that indirectly defend plants against their natural enemies. These indirect defenses may apply to soilborne plant diseases in both agricultural (Weller et al., 2002) and natural ecosystems (De Boer et al., 1998a, b).

Theoretical studies predict that invaders will occupy the same niche as the native species in the invaded ecosystem (Scheffer and Van Nes, 2006). However, meta-analyses show that invasive plant species have less pathogen and virus species than have similar native plant species (Mitchell and Power, 2003). These analyses have not yet been made for soil pathogens, but a worldwide study on root-feeding nematodes of an invasive grass (Ammophila arenaria) showed that in the non-native range plant roots were colonized by feeding generalists, but not by feeding specialists (Van der Putten et al., 2005). The sheer diversity of soil microbial communities (Torsvik et al., 1990) could provide a large reservoir of potential generalist pathogens for invasive plant species, and some studies indeed point at enemy exposure to soil pathogens of non-native plants in their new range (Beckstead and Parker, 2003; Knevel et al., 2004). The native pathogens that accumulate on the roots of the exotic plants might spread to native plants, which could be at indirect disadvantage in interspecific competition with the exotic species when the latter is more tolerant (Eppinga et al., 2006). This has not yet been shown for soil pathogens, but such indirect effects have been shown for aboveground viruses in Californian grasslands (Malmstrom et al., 2005).

Invasive soil pathogens that influence (semi)natural vegetation have been reported mainly from forests or ornamental trees. In Australia, the introduced pathogenic fungus Phytophthora cinnamomi had strong effects on Eucalyptus forests, where some species were killed and others survived (Weste, 1981; Peters and Weste, 1997). Armillaria luteobubalina, another introduced pathogen in Australia, has been shown to kill off $38 \%$ of all species in coastal ecosystems (Shearer et al., 1998). In California, Phytophthora ramorum causes sudden oak death and it has infected over 70 plant species in natural forests (Venette and Cohen, 2006). In Europe, interspecific hybridization of a Phytophthora pathogen that appears to result from a Phytophthora cambivora species and an unknown taxon similar to Phytophthora fragariae may have led to new host specificity of alder (Alnus) species (Brasier et al., 1999). Introduction of these soil-borne pathogens appear to have been encouraged by enhanced global trade (Brasier et al., 1999). Another source of invasive pathogens may be due to biological control of invasive weeds. One of the few examples is the use of soil-borne pathogens from the native range of the weed Euphorbia esula-virgata to control it in its new range (Kremer et al., 2006). However, these introduced enemies might be worse than the problem that they are intended to solve, for example, when they hybridize with local pathogens, or (as has been shown for introduced plague insects) switch to native hosts. Interestingly, most studies on pathogenic soil microbes in natural ecosystems deal 
with pathogenic fungi. Very little is known on pathogenic bacteria, and we do not know of any reports on invasive soil-borne bacterial pathogens.

In order to further enhance our capacity to predict invasiveness of exotic plants in relation to enemy release, more information is needed on plant traits that relate to control by soil-borne microbial enemies. In a grassland study, Klironomos (2002) observed that rare plants were more sensitive to development of negative soil feedback than were dominant plants. This would imply that rare plants, when released from their soil enemies, may become unexpectedly dominant when they move to a new range. On the other hand, in coastal foredunes, successive dominant plant species all developed negative soil feedback effects in parallel with changing environmental conditions (e.g., sand deposition; Van der Putten et al., 1993). This implies that plant dominance over successional time may be prolonged in the absence of soil pathogens. However, the introduced annual Conyza canadensis, despite being relatively insensitive to negative soil feedback, still disappears quite fast when secondary succession following land abandonment proceeds (Kardol et al., 2007).

\section{Invasive plants and soil microbial mutualistic symbionts}

The vast majority of plant species in terrestrial ecosystems form symbioses with rhizosphere microbes (Alexander, 1984; Smith and Read, 1997). A number of these microbes inhabit the rhizosphere, including mycorrhizal fungi, nitrogen-fixing bacteria and other plant-growth-promoting rhizobacteria (PGPR). These microbes can stimulate plant growth and reproduction by providing their hosts with services such as increased access to limiting nutrients (e.g., N, P) and protection from pathogens. In exchange, the plants provide these microbes with carbon. Such symbioses have been studied extensively from an agriculture and forestry context for several decades (Alexander, 1984; Smith and Read, 1997). Most of that research was conducted using a limited set of microbial isolates that provided high plant-growth responses in the laboratory and in managed ecosystems. However, more recently, it became clear that plant responses to such microbes were highly variable (Johnson et al., 1997), and it is this variation that stimulated new research on their potential roles in natural plant populations and communities. Recent research had made significant progress in better understanding the influence of symbioses on community diversity, species coexistence and invasion. Following two variables of the plant-microbe symbiosis are particularly important when considering the impact of a symbiosis on plant and microbial invasion: (a) variation in plant (or microbial) response to the interaction with the symbiont, and (b) variation in specialization of the symbiosis. These two variables will largely determine whether the symbiosis will affect the establishment and spread of the invader, and they must be considered from the point of view of the resident plants and microbes in the invaded community, as well as the invader.

Plants and their associated microbes can vary significantly in their response to associating with a symbiont. For example, arbuscular mycorrhizal (AM) fungi and some nitrogen-fixing bacteria are obligately dependent on host plants for completing their life cycles. In contrast, many ectomycorrhizal fungi and some PGPR are facultative symbionts. Similar variation can be seen from the plant perspective. For example, plants that associate with mycorrhizal fungi or Rhizobium are not typically obligately dependent on the symbiosis to complete their life cycle, but they do vary significantly in their response to the symbionts (from strong negative to positive responses) (Johnson et al., 1997; Denison and Kiers, 2004). Such responses have a genetic and environmental component. That is, in a common environment different plants do best when interacting with different fungal/bacterial species and genotypes; however, the strength of the response is largely mediated by the environmental conditions (strongest responses are typically observed under nutrient limiting conditions) (Denison and Kiers, 2004; Lekberg and Koide, 2005). In late-successional ecosystems, nutrient cycles are often more tightly closed, and thus nutrient availability is reduced for any individual plant. It has thus been postulated (Janos, 1980) (with some empirical evidence; e.g., Stinson et al., 2006) that dependency on symbioses is more pronounced in later successional ecosystems.

With all this background information, we can make a number of predictions on the impact of the symbiosis on plant/microbial invasions. Late-successional ecosystems, with increased plant dependency on symbiotic microbes, will be less invasible by potential invaders that do not form symbioses. In contrast, early-successional ecosystems will have a higher proportion of invasive plants that do not form microbial symbioses or respond little to the association. Such recently disturbed environments are expected to have higher nutrient availability in the soil, and possibly a soil microbial community, which contains a reduced diversity and abundance of mycorrhizal fungi, again favouring invasion by non-mycorrhizal plants.

There is some anecdotal evidence for a possible relationship between mycorrhizal independence and invasive potential of plant species. First, it has been observed that a large proportion of plants species considered invasive around the world are non-mycorrhizal or have low mycorrhizal dependency (Pysek, 1998; Vogelsang et al., 2004). Second, the vast majority of invasions occur in sites that have been recently disturbed (Mooney and Hobbs, 2000). Few plant species have successfully invaded 
late-successional ecosystems, and at least one species, Alliaria petiolata (a noxious invader of mature hardwood forests in eastern North America), is non-mycorrhizal, but produces allelochemicals that directly degrade AM fungi (Roberts and Anderson, 2001; Stinson et al., 2006). Through such positive feedback mechanisms, $A$. petiolata alters the mycorrhizal soil environment to one that is more conducive to its own growth and development rather than mycorrhizal-dependent native plants. Such degradation of local mycorrhizal fungi has also been noted for a variety of other invasive plants of disturbed ecosystems (although through other indirect mechanisms), leading to a new hypothesis for exotic plant invasion - the Mycorrhizal Degradation Hypothesis (Vogelsang et al., 2004). Additional evidence includes Myrica faya, a plant that brings along its nitrogen-fixing symbionts (Frankia spp.) as it invades forest communities in Hawaii (Vitousek and Walker, 1989), and Centaurea maculosa, a plant that invades grasslands in Western North America by connecting to the local mycorrhizal mycelial network (Marler et al., 1999).

The second major variable to consider is the degree of specialization between plant and microbial symbionts. Some plants and microbes associate with one or a few symbiont taxa (specialists), whereas others associate with a wide range of taxa (generalists) (MartinezRomero and CaballeroMellado, 1996; Smith and Read, 1997). Unfortunately, the degree of specialization in plant-microbe symbioses is not well understood, mainly because of the difficulties in assessing specialization. Plants may associate with a wide variety of microbes in lab conditions, but realized interactions in the field may be restricted to fewer taxa because of other extrinsic factors. A major limitation of field studies is that the approach typically used is correlational, and it is difficult to determine if any observed correspondence among symbionts is a result of genetic specificity or of some other environmental variable. Nonetheless, the degree of specificity has profound implications for the potential for plants to invade novel ecosystems and the potential for ecosystems to be impacted by the invasion.

A potentially invasive plant that forms a highly dependent and specialized symbiosis will likely have a difficult time establishing and spreading in the novel habitat, unless its required microbial symbiont is widespread, or is introduced at the same time (e.g., the introduction and invasion of Pinus spp. in much of the southern hemisphere was only successful following the introduction of suitable ectomycorrhizal fungal symbionts (Richardson et al., 1994)). Conversely, a symbiont-dependent plant that can associate with a wide variety of effective microbes, especially microbes that are widespread across continents, should have a higher probability of successful invasion. Similarly, native plants that are associated with a restricted group of microbial symbionts should have a higher probabil- ity of being affected by a noxious invader that degrades local mutualisms, compared to plants that are generalists. Overall, however, data are severely lacking, especially about microbial invasion patterns, despite their widespread introduction (Schwartz et al., 2006). Some preliminary data are available on some ectomycorrhizal fungi, such as Amanita muscaria introduced to Australia and New Zealand (Bougher, 1996), and the spread of Amanita phalloides to several continents from Europe (Pringle and Vellinga, 2006). However, a mechanistic understanding of such invasions by microbial symbionts is still far off.

\section{Invasive plants and saprotrophic microbes}

Saprophytic soil microbes show important feedbacks with plants, and these are usually positive because plants provide carbon-based resources for the saprophytes, which in turn regulate the supply of plant-available nutrients (Clarholm, 1989; Hamilton and Frank, 2001). Plant species can differ widely in their effects on saprophytic community structure particularly if they differ in key functional attributes (Saetre and Bååth, 2000; Wardle et al., 2003), and the structure of the saprophytic community in turn has important effects on soil processes including the supply from the soil of plant-available nutrients (Griffiths et al., 2000; Setälä and McLean, 2004). Therefore, it follows that invasive plant species that have different functional attributes to the native flora that they invade can influence saprophytic communities, soil processes, and ultimately plant nutrition and growth. However, the nature of these feedbacks is likely to be different to that described above for pathogenic and saprophytic microbes for two reasons. First, associations between plant species and saprophytic microbial species show much lower levels of specificity (Wardle et al., 2004). The saprophytic community associated with an invasive plant species will be driven primarily by the quality and quantity of the organic materials that the plant returns to the soil. Second, although Beijerink's law of 'all microbes are everywhere' continues to be debated (cf., Finlay, 2002; Foissner, 2006; Taylor et al., 2006), at the functional level most important groups of saprophytic microbes are likely to be represented in most soils even if at greatly varying densities. These two points, combined with the considerable functional redundancy that exists in saprophytic microbial communities (Setälä and McLean, 2004; Wertz et al., 2006), make it highly unlikely that invasive plant species 'escape' saprophytic microbes with particular functional capacities in their original environment or encounter new functional types of saprophytes in their new environment.

Differences in key traits between plant species are important determinants of saprophytic communities 
and the processes that they drive. It is recognized that plant species occupy a spectrum from those with acquisitive traits (fast growth, short-lived poorly defended tissues, high nutrient concentrations) to those with conservative traits (slow growth, long-lived well-defended tissues, low nutrient concentrations) (Grime et al., 1997; Díaz et al., 2004). This has consequences for the decomposer subsystem, because plants with acquisitive traits produce better quality resources for microbes, promote microbial communities with faster turnover rates, stimulate bacteria relative to fungi, and enhance microbially driven decomposition and nutrient mineralization rates (Wardle et al., 2004). Invasive plant species are most likely to have important effects on the decomposer subsystem when they occupy a different position on this trait spectrum to that occupied by the native species of the invaded habitat. As such, many studies have found invasive species to differ from the native species in the same community by growing faster and taller, and producing leaves with higher specific leaf areas and greater nutrient concentrations (Ehrenfeld, 2003, 2004; Allison and Vitousek, 2004), reflective of an acquisitive strategy. This has important implications for the quality of resources entering the belowground subsystem, and explains the greater rates of decomposition of litters often found for invasive plant species (Allison and Vitousek, 2004; Standish et al., 2004, but see; Pereira et al., 1998; Reinhart and VandeVoort, 2006). This in turn frequently results in invasive plant species exerting strong effects on the community structure of saprophytic microbes and their consumers (Wardle et al., 1995; Funk, 2005).

Changes in the soil saprophytic community caused by plant invasions have also been shown to promote decomposition rates of added substrates (Ashton et al., 2005; Hughes and Uowolo, 2006), and the supply rates from the soil of plant-available forms of nitrogen (Zou et al., 2006), phosphorus (Chapuis-Lardy et al., 2006) and other minerals (Vanderhoeven et al., 2005). Although reports of positive effects of invasive plants on the decomposer subsystem are common in the literature, they are not universal, and neutral and negative patterns have sometimes been reported depending on species and site conditions (Ehrenfeld, 2003). Nevertheless, observations showing that invasive plants can promote microbially driven processes and therefore supply from the soil of plant-available nutrients is suggestive of positive feedbacks between invasive plants and the saprophytic community. Such feedbacks have, however, yet to be explicitly demonstrated.

Invasive aboveground consumers also have the potential to indirectly affect the soil saprophytic community. Foliar herbivores influence the quantity and quality of organic matter returned to the soil through a range of mechanisms that can operate at both the whole plant and plant community level, and these can have either positive or negative effects on saprophytic microbes (Bardgett and Wardle, 2003). Invasive herbivores are most likely to have important effects when they differ greatly from the native herbivores present. For example, introduction of European Red Deer (Cervus elaphus) to New Zealand, a region that lacks native herbivorous mammals, has greatly influenced forest vegetation. A study of deer exclusion plots throughout New Zealand (Wardle et al., 2001) showed that deer invasion indirectly influenced soil saprophytic communities, but that the direction and magnitude of these effects depended on location and therefore context. Invasive aboveground predators can also induce cascading effects on soil saprophytic communities. For example, invasion of rats to offshore islands in New Zealand has been shown to adversely affect densities of soil saprophytic organisms, as a consequence of their predation of seabird chicks and therefore the disruption of seabird transfer of nutrients from the ocean to the land (Fukami et al., 2006).

We are not aware of any studies that have explicitly identified invasions of saprophytic microbial species into new communities. Should such invasions have occurred they would probably remain undetected for two reasons. First, our knowledge of the taxonomy of saprophytic microbes at the species level is limited and most taxa remain undescribed. Second, given the considerable diversity and functional capacity of the microbial saprophytic community, it is highly unlikely that an invasive microbe would contain sufficiently novel functional attributes for its ecological impact to be detectable. Important impacts of invasive saprophytes are probably restricted to large bodied saprophytic animals that are constrained by biogeography. For example, invasions of earthworms to regions that lack native earthworms, such as formerly glaciated regions of North America, can exert important effects on saprophytic microbial communities (McLean and Parkinson, 2000). Invasive earthworms are increasingly recognized as exerting large effects on microbially driven soil processes, organic matter loss and ultimately plant growth (Bohlen et al., 2004). Another example involves the invasion of the New Zealand flatworm Aryhurdendyus triangulata, a predator of earthworms, to parts of Europe. Reduction of earthworms by this predator has probably greatly affected saprophytic microbes and their activities, and appears to have caused important changes in soil properties, moisture dynamics and vegetation (Boag and Yeates, 2001).

\section{Discussion, conclusions and perspectives}

There are big differences between how saprophytic vs pathogenic/symbiotic microbes interact with invasive plants. The number of examples that point 
at specificity of soil-borne pathogens is increasing rapidly, showing that these microbes can have important effects on the composition and functioning of plant communities (Van der Putten, 2003). Similar effects have been demonstrated for symbiotic mutualists (Grime et al., 1987), although a limitation of studies on symbionts may be due to the frequent use of a limited subset of species originating from culture collections (Klironomos, 2003). For example, Arbuscular Mycorrhizal Fungi (AMF) are obligate biotrophs and considered to be generalists. However, isolates are isolated and kept in culture using generalist crop plants. Thus, it is likely that any specialists that may exist in the soil are not even cultured to begin with.

Saprophytic microbes interact with litter, not with live plants, and therefore have far less specificity. Decomposer microbes are most likely to be influenced by litter quality and therefore plant traits that affect litter quality. Invasive plants have their biggest effect on saprophytes when their traits differ most from that of native species. Decomposer organisms that feed on root exudates, however, are more specific than general litter decomposer microorganisms, so that effects of invasive plants, as of any plant, will be stronger on rhizosphere decomposer microbes than on microbes that are decomposing litter in the bulk soil. A major drawback of the published literature is that invasiveness has been studied from the perspective of either pathogens, or symbionts or decomposers without much attention for the integration of these three types of microbeplant interactions in the rhizosphere. As plantpathogen and plant-decomposer interactions depend very much on each other, as well as on soil nutrient availability, we propose that future studies need to integrate these types of plant-microbe interactions and to study their inter-dependencies (Figure 1).

There are relatively few studies on invasive soil pathogens, fewer on invasive symbionts and virtually none on invasive decomposer organisms. The examples on invasive soil pathogens, the lack of suitable mycorrhizal fungi when establishing new forest plantations and invasive plants that escape from their native soil pathogens all suggest that Beijerinck's law that 'everything is everywhere but environment selects' (Nekola and White, 1999) does not necessarily hold for soil microbes that are most intimately associated with plant roots. A major area for further investigation is to better understand the relative importance of saprophytic, pathogenic and symbiotic microbes in facilitating the success of invasive species, and in which contexts different microbes are likely to be important (Wardle et al., 2004). For example, interactions with saprophytes will be more important in nutrient limited systems, whereas the balance between symbionts and pathogens may shift along successional trajectories (Reynolds et al., 2003; Kardol et al., 2006).

Most, if not all, studies on invasive plants, pathogens and symbionts are focused on bi-trophic interactions of plants and soil microbes. However, soil communities also consist of natural enemies of soil microbes, such as saprophytic microbes, which may act as antagonists or helper organisms of pathogens and mycorrhizal fungi (Smith and Read, 1997; De Boer et al., 1998a,b). Soil microbes are also antagonistic against soil invertebrates (e.g. rootfeeding nematodes). Little is known, for example, on how plants may recruit belowground microbes for defense against soil pathogens or root-feeding nematodes. In natural ecosystems, naturally coevolved belowground multitrophic interactions may be considerably disrupted when either plants or soil microbes are invading, or when plants or soil microbes are moved to novel environments. Community reorganizations will lead to altered patterns of bottom-up and top-down control interactions and to altered direct and indirect interactions in the rhizosphere. Such multitrophic level interactions in soil food webs most likely affect local abundance of the exotic or of the native species; however, we have a poor understanding of how and at what scales they operate and of their consequences for species interactions, community composition and ecosystem processes (Figure 1).

In conclusion, soil microbes play a critical role in the functioning of natural ecosystems, and moving plants, animals or microbes around the globe can have a major impact on the abundance of individual species, the diversity of native communities or the functioning of entire ecosystems. Awareness is growing that the critical role of microbes is a major aspect to be considered within the context of biological invasions. We propose that our ability to understand, predict and counteract biological invasions will benefit from linking work on plant-related pathogenic, symbiotic and decomposer microbes in an above-belowground multitrophic conceptual framework.

\section{Acknowledgements}

We thank Pella Brinkman for logistic support, the Dutch Earth and Life Sciences Council (ALW) for VICI-grant funding to WvdP and the Natural Sciences and Engineering Research Council of Canada for funding to JNK. This is NIOO-KNAW publication 4012.

\section{References}

Agrawal AA, Kotanen PM, Mitchell CE, Power AG, Godsoe W, Klironomos J. (2005). Enemy release? An experiment with congeneric plant pairs and diverse above- and belowground enemies. Ecology 86: 2979-2989.

Alexander M. (1984). Biological Nitrogen Fixation: Ecology, Technology, and Physiology. Plenum Press: New York.

Allison SD, Vitousek PM. (2004). Rapid nutrient cycling in leaf litter from invasive plants in Hawai'i. Oecologia 141: $612-619$. 
Ashton IW, Hyatt LA, Howe KM, Gurevitch J, Lerdau MT. (2005). Invasive species accelerate decomposition and litter nitrogen loss in a mixed deciduous forest. Ecol Appl 15: 1263-1272.

Bardgett RD, Wardle DA. (2003). Herbivore-mediated linkages between aboveground and belowground communities. Ecology 84: 2258-2268.

Beckstead J, Parker IM. (2003). Invasiveness of Ammophila arenaria: release from soil-borne pathogens? Ecology 84: 2824-2831.

Bever JD. (1994). Feedback between plants and their soil communities in an old field community. Ecology 75: 1965-1977.

Bever JD. (2003). Soil community feedback and the coexistence of competitors: conceptual frameworks and empirical tests. New Phytol 157: 465-473.

Bever JD, Westover KM, Antonovics J. (1997). Incorporating the soil community into plant population dynamics: the utility of the feedback approach. J Ecol 85: $561-573$.

Boag B, Yeates GW. (2001). The potential impact of the New Zealand flatworm, a predator of earthworms, in western Europe. Ecol Appl 11: 1276-1286.

Bohlen PJ, Scheu S, Hale CM, McLean MA, Migge S, Groffman PM et al. (2004). Non-native invasive earthworms as agents of change in northern temperate forests. Front Ecol Environ 2: 427-435.

Bougher NL. (1996). Diversity of ectomycorrhizal fungi associated with eucalypts in Australia. In: Brundrett M, Dell B, Malajczuk N, Minquin G (eds). Mycorrhizas for Plantation Forestry in Asia. Australian Centre for International Research: Canberra, pp 8-15.

Brasier CM, Cooke DEL, Duncan JM. (1999). Origin of a new Phytophthora pathogen through interspecific hybridization. Proc Natl Acad Sci USA 96: 5878-5883.

Burdon JJ. (1987). Diseases and Plant Population Biology. Cambridge University Press: Cambridge, UK.

Burdon JJ. (1993). The structure of pathogen populations in natural plant-communities. Annu Rev Phytopathol 31: 305-323.

Callaway RM, Thelen GC, Barth S, Ramsey PW, Gannon JE. (2004). Soil fungi alter interactions between the invader Centaurea maculosa and North American natives. Ecology 85: 1062-1071.

Chapuis-Lardy L, Vanderhoeven S, Dassonville N, Koutika LS, Meerts P. (2006). Effect of the exotic invasive plant Solidago gigantea on soil phosphorus status. Biol Fertil Soils 42: 481-489.

Clarholm M. (1989). Effects of plant-bacterial-amebal interactions on plant uptake of nitrogen under field conditions. Biol Fertil Soils 8: 373-378.

Clay K, Kover PX. (1996). The Red Queen Hypothesis and plant/pathogen interactions. Annu Rev Phytopathol 34: $29-50$.

De Boer W, Klein Gunnewiek PJA, Lafeber P, Janse JD, Spit BE, Woldendorp JW. (1998a). Anti-fungal properties of chitinolytic dune soil bacteria. Soil Biol Biochem 30: 193-203.

De Boer W, Klein Gunnewiek PJA, Woldendorp JW. (1998b). Suppression of hyphal growth of soil-borne fungi by dune soils from vigorous and declining stands of Ammophila arenaria. New Phytol 138: 107-116.

De Rooij-Van der Goes PCEM. (1995). The role of plantparasitic nematodes and soil-borne fungi in the decline of Ammophila arenaria (L.) Link. New Phytol 129: $661-669$.
Denison RF, Kiers ET. (2004). Lifestyle alternatives for rhizobia: mutualism, parasitism, and forgoing symbiosis. FEMS Microbiol Lett 237: 187-193.

Díaz S, Hodgson JG, Thompson K, Cabido M, Cornelissen JHC, Jalili A et al. (2004). The plant traits that drive ecosystems: evidence from three continents. J Veg Sci 15: 295-304.

Ehrenfeld JG. (2003). Effects of exotic plant invasions on soil nutrient cycling processes. Ecosystems 6: 503-523.

Ehrenfeld JG. (2004). Implications of invasive species for belowground community and nutrient. Weed Technol 18: $1232-1235$.

Elton CS. (1958). The Ecology of Invasions by Animals and Plants. Methuen: London.

Eppinga MB, Rietkerk M, Dekker SC, De Ruiter PC, Van der Putten WH. (2006). Accumulation of local pathogens: a new hypothesis to explain exotic plant invasions. Oikos 114: 168-176.

Finlay BJ. (2002). Global dispersal of free-living microbial eukaryote species. Science 296: 1061-1063.

Foissner W. (2006). Biogeography and dispersal of microorganisms: a review emphasizing protists. Acta Protozool 45: 111-136.

Fukami T, Wardle DA, Bellingham PJ, Mulder CPH, Towns DR, Yeates GW et al. (2006). Above- and below-ground impacts of introduced predators in seabird-dominated island ecosystems. Ecol Lett 9: 1299-1307.

Funk JL. (2005). Hedychium gardnerianum invasion into Hawaiian montane rainforest: interactions among litter quality, decomposition rate, and soil nitrogen availability. Biogeochemistry 76: 441-451.

Gerlach J. (2001). Predator, prey and pathogen interactions in introduced snail populations. Anim Conserv 4: 203-209.

Grayston SJ, Wang SQ, Campbell CD, Edwards AC. (1998). Selective influence of plant species on microbial diversity in the rhizosphere. Soil Biol Biochem 30: 369-378.

Griffiths BS, Ritz K, Bardgett RD, Cook R, Christensen S, Ekelund $\mathrm{F}$ et al. (2000). Ecosystem response of pasture soil communities to fumigation-induced microbial diversity reductions: an examination of the biodiversity-ecosystem function relationship. Oikos 90: 279-294.

Grime JP, Mackey JM, Hillier SH, Read DJ. (1987). Floristic diversity in a model system using experimental microcosms. Nature 328: 420-422.

Grime JP, Thompson K, Hunt R, Hodgson JG, Cornelissen JHC, Rorison IH et al. (1997). Integrated screening validates primary axes of specialisation in plants. Oikos 79: 259-281.

Hamilton EW, Frank DA. (2001). Can plants stimulate soil microbes and their own nutrient supply? Evidence from a grazing tolerant grass. Ecology 82: 2397-2402.

Hooper DU, Bignell DE, Brown VK, Brussaard L, Dangerfield JM, Wall DH et al. (2000). Interactions between aboveground and belowground biodiversity in terrestrial ecosystems: patterns, mechanisms, and feedbacks. Bioscience 50: 1049-1061.

Hughes RF, Uowolo A. (2006). Impacts of Falcataria moluccana invasion on decomposition in Hawaiian lowland wet forests: the importance of stand-level controls. Ecosystems 9: 977-991.

Janos DP. (1980). Mycorrhizae influence tropical succession. Biotropica 12: 56-64. 
Johnson NC, Graham JH, Smith FA. (1997). Functioning of mycorrhizal associations along the mutualism-parasitism continuum. New Phytol 135: 575-586.

Jules ES, Kauffman MJ, Ritts WD, Carroll AL. (2002). Spread of an invasive pathogen over a variable landscape: a nonnative root rot on Port Orford cedar. Ecology 83: 3167-3181.

Kardol P, Bezemer TM, Van der Putten WH. (2006). Temporal variation in plant-soil feedback controls succession. Ecol Lett 9: 1080-1088.

Kardol P, Cornips NJ, Van Kempen MML, Bakx-Schotman JMT, Van der Putten WH. (2007). Microbe-mediated plant-soil feedback causes historical contingency effects in plant community assembly. Ecol Monogr (in press).

Keane RM, Crawley MJ. (2002). Exotic plant invasions and the enemy release hypothesis. Trends Ecol Evol 17: 164-170.

Klironomos JN. (2002). Feedback with soil biota contributes to plant rarity and invasiveness in communities. Nature 417: 67-70.

Klironomos JN. (2003). Variation in plant response to native and exotic arbuscular mycorrhizal fungi. Ecology 84: 2292-2301.

Knevel IC, Lans T, Menting FBJ, Hertling UM, van der Putten WH. (2004). Release from native root herbivores and biotic resistance by soil pathogens in a new habitat both affect the alien Ammophila arenaria in South Africa. Oecologia 141: 502-510.

Kowalchuk GA, Buma DS, de Boer W, Klinkhamer PGL, van Veen JA. (2002). Effects of above-ground plant species composition and diversity on the diversity of soil-borne microorganisms. Antonie Van Leeuwenhoek Int J Gen Mol Microbiol 81: 509-520.

Kremer RJ, Caesar AJ, Souissi T. (2006). Soilborne microorganisms of Euphorbia are potential biological control agents of the invasive weed leafy spurge. Appl Soil Ecol 32: 27-37.

Lavelle P, Blanchart E, Martin A, Martin S, Spain A, Toutain $\mathrm{F}$ et al. (1993). A hierarchical model for decomposition in terrestrial ecosystems - application to soils of the humid tropics. Biotropica 25: 130-150.

Lekberg Y, Koide RT. (2005). Is plant performance limited by abundance of arbuscular mycorrhizal fungi? A meta-analysis of studies published between 1988 and 2003. New Phytol 168: 189-204.

Levine JM, Vila M, D’Antonio CM, Dukes JS, Grigulis K, Lavorel S. (2003). Mechanisms underlying the impacts of exotic plant invasions. Proc $R$ Soc Lond B Biol Sci 270: $775-781$.

Liebhold AM, Macdonald WL, Bergdahl D, Maestro VC. (1995). Invasion by exotic forest pests - a threat to forest ecosystems. For Sci 41: 1-49.

Malmstrom CM, McCullough AJ, Johnson HA, Newton LA, Borer ET. (2005). Invasive annual grasses indirectly increase virus incidence in California native perennial bunchgrasses. Oecologia 145: 153-164.

Marilley L, Vogt G, Blanc M, Aragno M. (1998). Bacterial diversity in the bulk soil and rhizosphere fractions of Lolium perenne and Trifolium repens as revealed by PCR restriction analysis of $16 \mathrm{~S}$ rDNA. Plant Soil 198: 219-224.

Marler MJ, Zabinski CA, Callaway RM. (1999). Mycorrhizae indirectly enhance competitive effects of an invasive forb on a native bunchgrass. Ecology 80: 1180-1186.
MartinezRomero E, CaballeroMellado J. (1996). Rhizobium phylogenies and bacterial genetic diversity. Crit Rev Plant Sci 15: 113-140.

McLean MA, Parkinson D. (2000). Field evidence of the effects of the epigeic earthworm Dendrobaena octaedra the microfungal community in pine forest floor. Soil Biol Biochem 32: 351-360.

Mills KE, Bever JD. (1998). Maintenance of diversity within plant communities: soil pathogens as agents of negative feedback. Ecology 79: 1595-1601.

Mitchell CE, Power AG. (2003). Release of invasive plants from fungal and viral pathogens. Nature 421: 625-627.

Mooney HA, Hobbs R. (2000). Invasive Species in a Changing World. Island Press: Washington.

Nekola JC, White PS. (1999). The distance decay of similarity in biogeography and ecology. $J$ Biogeogr 26: 867-878.

Niwa S, Iwano H, Asada S, Matsuura M, Goka K. (2004). A microsporidian pathogen isolated from a colony of the European bumblebee, Bombus terrestris, and infectivity on Japanese bumblebee. Jpn J Appl Entomol Zool 48: $60-64$.

Packer A, Clay K. (2000). Soil pathogens and spatial patterns of seedling mortality in a temperate tree. Nature 404: 278-281.

Pereira AP, Graca MAS, Molles M. (1998). Leaf litter decomposition in relation to litter physico-chemical properties, fungal biomass, arthropod colonization, and geographical origin of plant species. Pedobiologia 42: 316-327.

Peters D, Weste G. (1997). The impact of Phytophthora cinnamomi on six rare native tree and shrub species in the Brisbane Ranges, Victoria. Aust J Bot 45: 975-995.

Pringle A, Vellinga EC. (2006). Last chance to know? Using literature to explore the biogeography and invasion biology of the death cap mushroom Amanita phalloides (Vaill. Ex fr.: Fr.) link. Biol Invasions 8: 1131-1144.

Pysek P. (1998). Is there a taxonomic pattern to plant invasions? Oikos 82: 282-294.

Reinhart KO, Callaway RM. (2006). Soil biota and invasive plants. New Phytol 170: 445-457.

Reinhart KO, Packer A, Van der Putten WH, Clay K. (2003). Plant-soil biota interactions and spatial distribution of black cherry in its native and invasive ranges. Ecol Lett 6: 1046-1050.

Reinhart KO, VandeVoort R. (2006). Effect of native and exotic leaf litter on macroinvertebrate communities and decomposition in a western Montana stream. Divers Distrib 12: 776-781.

Reynolds HL, Packer A, Bever JD, Clay K. (2003). Grassroots ecology: plant-microbe-soil interactions as drivers of plant community structure and dynamics. Ecology 84: 2281-2291.

Richardson DM, Williams PA, Hobbs RJ. (1994). Pine invasions in the Southern Hemisphere - determinants of spread and invadability. J Biogeogr 21: 511-527.

Roberts KJ, Anderson RC. (2001). Effect of garlic mustard [Alliaria petiolata (Beib. Cavara \& Grande)] extracts on plants and arbuscular mycorrhizal (AM) fungi. Am Midl Nat 146: 146-152.

Saetre P, Bååth E. (2000). Spatial variation and patterns of soil microbial community structure in a mixed sprucebirch stand. Soil Biol Biochem 32: 909-917.

Scheffer M, Van Nes EH. (2006). Self-organized similarity, the evolutionary emergence of groups of similar species. Proc Natl Acad Sci USA 103: 6230-6235. 
Scheu S. (2001). Plants and generalist predators as links between the below-ground and above-ground system. Basic Appl Ecol 2: 3-13.

Schwartz MW, Hoeksema JD, Gehring CA, Johnson NC, Klironomos JN, Abbott LK et al. (2006). The promise and the potential consequences of the global transport of mycorrhizal fungal inoculum. Ecol Lett 9: 501-515.

Setälä H, McLean MA. (2004). Decomposition rate of organic substrates in relation to the species diversity of soil saprophytic fungi. Oecologia 139: 98-107.

Shearer BL, Crane CE, Fairman RG, Grant MJ. (1998). Susceptibility of plant species in coastal dune vegetation of southwestern Australia to killing by Armillaria luteobubalina. Aust J Bot 46: 321-334.

Smith SE, Read DJ. (1997). Mycorrhizal Symbioses. Academic Press: London.

Standish RJ, Williams PA, Robertson AW, Scott NA, Hedderley DI. (2004). Invasion by a perennial herb increases decomposition rate and alters nutrient availability in warm temperate lowland forest remnants. Biol Invasions 6: 71-81.

Stinson KA, Campbell SA, Powell JR, Wolfe BE, Callaway RM, Thelen GC et al. (2006). Invasive plant suppresses the growth of native tree seedlings by disrupting belowground mutualisms. Plos Biol 4: 727-731.

Swift MJ, Heal OW, Anderson JM. (1979). Decomposition in Terrestrial Ecosystems. Blackwell: Oxford.

Taylor JW, Turner E, Townsend JP, Dettman JR, Jacobson D. (2006). Eukaryotic microbes, species recognition and the geographic limits of species: examples from the kingdom Fungi. Philos Trans $R$ Soc B Biol Sci 361: 1947-1963.

Torsvik V, Goksøyr J, Daae FL. (1990). High diversity in DNA of soil bacteria. Appl Environ Microbiol 56: 782-787.

Van Breemen N, Finzi AC. (1998). Plant-soil interactions: ecological aspects and evolutionary implications. Biogeochemistry 42: 1-19.

Van der Putten WH. (2003). Plant defense belowground and spatiotemporal processes in natural vegetation. Ecology 84: 2269-2280.

Van der Putten WH, Kowalchuk GA, Brinkman EP, Doodeman GTA, Van der Kaaij RM, Kamp AFD et al. (2007). Soil feedback of exotic savanna grass relates to the absence of pathogens and selective mycorrhizal fungi. Ecology (in press).

Van der Putten WH, Van Dijk C, Peters BAM. (1993). Plantspecific soil-borne diseases contribute to succession in foredune vegetation. Nature 362: 53-56.

Van der Putten WH, Vet LEM, Harvey JA, Wäckers FL. (2001). Linking above- and belowground multitrophic interactions of plants, herbivores, pathogens, and their antagonists. Trends Ecol Evol 16: 547-554.

Van der Putten WH, Yeates GW, Duyts H, Reis CS, Karssen G. (2005). Invasive plants and their escape from root herbivory: a worldwide comparison of the root-feeding nematode communities of the dune grass Ammophila arenaria in natural and introduced ranges. Biol Invasions 7: 733-746.

Vanderhoeven S, Dassonville N, Meerts P. (2005). Increased topsoil mineral nutrient concentrations under exotic invasive plants in Belgium. Plant Soil 275: 169-179.

Venette RC, Cohen SD. (2006). Potential climatic suitability for establishment of Phytophthora ramorum within the contiguous United States. For Ecol Manage 231: 18-26.

Vitousek PM, Gosz JR, Grier CC, Melillo JM, Reiners WA, Todd RL. (1979). Nitrate losses from disturbed ecosystems. Science 204: 469-474.

Vitousek PM, Walker LR. (1989). Biological invasion by Myrica faya in Hawaii - plant demography, nitrogenfixation, ecosystem effects. Ecol Monogr 59: 247-265.

Vogelsang KM, Bever JD, Griswold M, Schulz PA. (2004). The use of mycorrhizal fungi in erosion control applications. Final report for Caltrans. California Department of Transportation Contract no. 65A0070, Sacramento (California).

Wardle DA. (2002). Communities and Ecosystems: Linking the Aboveground and Belowground Components. Princeton University Press: Princeton, USA.

Wardle DA, Bardgett RD, Klironomos JN, Setälä H, Van der Putten WH, Wall DH. (2004). Ecological linkages between aboveground and belowground biota. Science 304: 1629-1633.

Wardle DA, Barker GM, Yeates GW, Bonner KI, Ghani A. (2001). Introduced browsing mammals in New Zealand natural forests: aboveground and belowground consequences. Ecol Monogr 71: 587-614.

Wardle DA, Nicholson KS, Rahman A. (1995). Ecological effects of the invasive weed species Senecio jacobaea L. (ragwort) in a New Zealand pasture. Agric Ecosyst Environ 56: 19-28.

Wardle DA, Yeates GW, Williamson W, Bonner KI. (2003). The response of a three trophic level soil food web to the identity and diversity of plant species and functional groups. Oikos 102: 45-56.

Waring KM, O'Hara KL. (2005). Silvicultural strategies in forest ecosystems affected by introduced pests. For Ecol Manage 209: 27-41.

Weller DM, Raaijmakers JM, Gardener BBM, Thomashow LS. (2002). Microbial populations responsible for specific soil suppressiveness to plant pathogens Annu Rev Phytopathol 40: 309-348.

Wertz S, Degrange V, Prosser JI, Poly F, Commeaux C, Freitag T et al. (2006). Maintenance of soil functioning following erosion of microbial diversity. Environ Microbiol 8: 2162-2169.

Weste G. (1981). Changes in the vegetation of sclerophyll shrubby woodland associated with invasion by Phytophthora cinnamomi. Aust J Bot 29: 261-276.

Williamson M. (1996). Biological Invasions. Chapman and Hall: London.

Wolters V, Silver WL, Bignell DE, Coleman DC, Lavelle P, Van der Putten WH et al. (2000). Effects of global changes on above- and belowground biodiversity in terrestrial ecosystems: implications for ecosystem functioning. Bioscience 50: 1089-1098.

Zou JW, Rogers WE, DeWalt SJ, Siemann E. (2006). The effect of Chinese tallow tree (Sapium sebiferum) ecotype on soil-plant system carbon and nitrogen processes. Oecologia 150: 272-281. 